\title{
May Joseph. Sea Log, Indian Ocean to New York.
}

\section{Kerry-Jane Wallart}

\section{(2) OpenEdition}

\section{Journals}

Electronic version

URL: https://journals.openedition.org/ces/2088

DOI: $10.4000 /$ ces. 2088

ISSN: 2534-6695

\section{Publisher}

SEPC (Société d'études des pays du Commonwealth)

Electronic reference

Kerry-Jane Wallart, "May Joseph. Sea Log, Indian Ocean to New York.", Commonwealth Essays and Studies [Online], 42.2 | 2020, Online since 28 September 2020, connection on 18 January 2022. URL: http://journals.openedition.org/ces/2088 ; DOI: https://doi.org/10.4000/ces.2088

This text was automatically generated on 18 January 2022

\section{(c) $)(9)$}

Commonwealth Essays and Studies is licensed under a Licence Creative Commons Attribution - Pas d'Utilisation Commerciale - Pas de Modification 4.0 International. 


\title{
May Joseph. Sea Log, Indian Ocean to New York.
}

\author{
Kerry-Jane Wallart
}

\section{REFERENCES}

New York: Routledge. 147 p. ISBN 978113808 8337. £96.

1 Even in 2020, with cultural studies scholarship exploring ever more hybrid methodologies, this volume is difficult to assess synthetically. Not only does it convoke a cluster of theoretical standpoints, but it also reads like an essay or an autobiographical piece, multiplying the modes of address. Christina Sharpe's In the Wake (2013) is mentioned as early as the introduction: May Joseph is tackling the Indian Ocean in ways that expand Sharpe's discussion of the Atlantic and the Mediterranean and the volume operates a similar collapse of scales and orders, starting with the distinction between public and private selves. This "Sea Log" charters "the decimated landscapes across the former colonies" (41) alongside the journeys which took Joseph's parents from Kerala to Dar es Salaam, which took her to Manhattan, where she teaches, and her mother "back" to Koulang/Quilon.

2 Joseph traces her research back to an interest in the Indian coastal cultures which have developed in "the numerous barrier islands and archipelagic floating land masses that constitute the extended coastline" (7) in the South East of India, far away from landlocked and increasingly Hindu-centred Delhi. This matrix of colonial encounters (between the Dutch and the Indonesians, the Portuguese and the Jews, the East Africans and the Maldives sailors) progressively enters a vortex of diasporic experiences and imaginations and "morph[s] into [...] the self-ethnography of one emergent feminist subject" (9). The dimension of self-ethnography, a signposted adaptation of Pratt's auto-ethnographic hypothesis, culminates with poems $(50,118)$ and sub-sections resembling diary entries $(1,30,40,86,110,119,124)$. 
3 The most evident framework within which Sea Log reads is that of the spatial turn Lefebvre is quoted in the introduction and each of the 10 chapters captures the undertow of affects and social interactions provoked by senses of place. Part I, entitled "Navigations," scrutinizes oceanic consciousness with a distinct emphasis on the archipelagic coastline of Kerala and its connections with other neighbouring shores scarred by land and human exploitation, while Part II, "Periplus," isolates five spaces (Cochin, Dar es Salaam, Hanoi, Bamiyan and New York); a final chapter, "Deciphering the Indian Ocean," functions both as a conclusion following the "aftershock" of Hurricane Sandy in Manhattan, and as an open-ended interrogation around Bruno Latour's theory of our global contemporary "paralysis of thought" in "'facing Gaia" (135).

4 The volume re-shuffles the concepts of transculturalism, migration studies and diasporic studies. In ways that are reminiscent of Lisa Lowe's landmark Intimacies of Four Continents (2015), Joseph sees Cochin and New York harbours as "mnemonic reminder[s]" (78) of one another. Building upon the now established parallel between the Middle Passage and the Kala Pani in their contributions to forms of creolization, Joseph enlarges the scope to discussions of Ho Chi Minh's and Fanon's experiences of European racism; she examines such ongoing ethical scandals as "the unspeakable past of slavery" (85), from the slave pen of Bagamoyo in Tanzania to Trouillot's Haitian narratives of Sans Souci (5-6) and to the fort of Thangassery in Kerala (20-21); she also follows the trans-oceanic exchanges of cultural and linguistic practices, delinking hegemonic knowledge but linking "chai in Swahili and chaya in Malayalam [...][,] an ocean in a cup of tea" (96).

5 The sonic and visual reverberations across the Indian Ocean recorded here are often attuned to "fragments of environmenting" (6): a helpless contemplation of coastline devastations which started with the Early Modern European expansionist presence. The prism of environmental disaster through which Joseph navigates the Indian Ocean is connected to Mignolo's decolonial imperative. Joseph acknowledges the importance of her formative years in the "socialist utopia" (84-98) of Julius Nyerere and the emphasis laid in school programmes on ujamaa (self-reliance), a hopeful attempt at inventing a post-colonial modernity which resonates with Kerala communism and some Latin American movements of the 1970 s.

6 Lastly, the book is traversed by a reflection on feminist affect. The feminine line opens with an ancestor, a "kept woman" (the euphemism for "slave" used by Joseph's uncle) who was possibly deported from Indonesia to Kerala by the Dutch. What starts as a piece of subaltern studies scholarship evolves into a take on Glissant's "knowledge becoming" and on Sara Ahmed's "feelings of structure" (although Ahmed does not appear in the monograph - another odd absence being that of Arundhati Roy). At the end of this archipelagic exploration of feminine knowledge, a brief discussion of Vandana Shiva's watery psycho-geographies brings the reader back to the urgency of praxis and activism.

7 Sea Log is packed with perspectival twists, personal "shocks" and excavated microhistories. One of the few reservations which could be formulated is the editorial choice of compartmentalizing chapters (with a distinct bibliography at the end of each of them) and parts; one would have liked to see the text presented as more of a flow - as it were. Another readerly frustration lies in its relative lack of analyses of cultural objects, textualities and critical interventions from the cultures of the subcontinent, 
the author giving preference to such classically "Black Atlantic" names as Fanon, Senghor, Artaud, Césaire, Pessoa, Glissant, or more recently, Moten and Harney. In fact, one of the most original articulations is constituted by an analysis of Gandhi's Key to Health where Joseph delinks conceptions of desire and food consumption as they have been elaborated by structuralist anthropology. A case study of trans-oceanic migration, Gandhi undermines biopower by disengaging the body through hunger: "a strategic intervention against the practices of pillage" (116). The same page becomes even more interesting when the author looks at how North Americans eat without restraint. She writes "we Americans" - acknowledging the fact that the colonized and the colonizer live tangled lives indeed, but also that the slave $b(r)$ ought from Indonesia could only have her story unearthed by an academic positionality speaking from the Global North.

\section{NOTES}

1. Sara Ahmed, "Happy Objects," in The Affect Theory Reader, ed. Melissa Gregg and Gregory Seigworth, (Durham: Duke University Press, 2010), 29-51.

\section{AUTHORS}

\section{KERRY-JANE WALLART}

Université d'Orléans, REMELICE

Kerry-Jane Wallart teaches Black Atlantic literatures and Postcolonial theory at the University of Orleans. She has authored over 40 articles and book chapters in these fields, with a focus on Caribbean authors. She has co-edited three issues of Commonwealth Essays and Studies, one issue of Revue de littérature comparée and one issue of Women: A Cultural Review. She is the co-editor of a volume concerned with the works of Jamaica Kincaid (Wagadu, 2019), and of a forthcoming volume on the transnational dimension of Jean Rhys's fiction (Bloomsbury, 2020). 